\title{
PSYCHE
}

\section{ANTS FROM THE SUMMIT OF MOUNT WASHINGTON.}

BY WILLIAM MORTON WHEELER, NEW YORK, N. Y.

During the past year Mrs. Annie Trumbull Slosson spent several months on the summit of Mount Washington, N. H., collecting and studying the insects. She has kindly sent me all the species of ants she succeeded in taking. Though the collection is a small one, as this group of insects was very poorly represented on the summit, it is nevertheless of more than usual interest. It comprises the following forms:

I. Cumponotus herculeanus ligniperdus Latreille var. pictus. Forel. A single deälated female. My collection contains two very similar specimens taken during August $190 \mathrm{r}$ in the same locality by Dr. C. S. Bacon.

2. Formica sanguinea ascrva Forel. Two deillated females. I have recently found two colonies of this form in the Litchfield Hills, Conn, at an altitude of about $1000 \mathrm{ft}$. The females are rather small $(7-8 \mathrm{~mm}$.) compared with those of our more abundant $F$. sanguinea rubicunda. The gaster and head are black, the thorax and petiole dnll yellowish brown, the former mottled with black, the legs and antennae dark brown. The rich red color of our common forms of sanguinea is completely lacking. The clypeal notch is broad and deep.

3. Lasius niger L. var. americanus Emery. A single winged female of very small size $(5.3 \mathrm{~mm}$.) but in other respects like the common form.

4. Lasius umbratus mixtus Nylander var. Three males and two winged females resembling the corresponding sexes of var. aphidicola Walsh, except that the females collected by Mrs. Slosson are decidedly darker.

5. Dolichoderus taschenbergi Mayr var. gagates Wheeler. A single deälated specimen of the hitherto unknown female of this species and variety. It measures $4 \mathrm{~mm}$. and resembles the worker in the structure of the epinotum. The head and thorax are very smooth and shining, the epinotum somewhat more opaque, with scattered shallow foveolx. The body and appendages are deep black, the tips of the mandibles and articulations of the legs slightly brownish.

6. Leptothorax aceriorum canadensis Provancher. Three deälated females all darker than the females of the typical form in my collection.

7. Myrmica rubra brevinodis Emery var. A single winged female differing 
from the typical form in being of smaller size and much darker color and in having the antennal scape somewhat straighter at the base.

8. Myrmica rubra scabrinodis Nylander var. A single deälated female belonging to a form of this subspecies with a small calyculate dilatation at the base of the antennal scape, long straight epinotal spines and strong sculpturing on the head, thorax and pedicel.

9. Myrmica rubra scabrinodis Nylander var. schencki Emery. A single winged female taken by Dr. C.S. Bacon during August $190 \mathrm{r}$ on the summit. This insect is darker in color than females from Colebrook, Conn., in my collection.

This little collection of ants is remarkable because it comprises males and females but no workers. This fact taken in connection with Mrs. Slosson's statement to me that she was quite unable to find any colonies of ants on the summit, but at most chance aggregates of two or three females, indicates that this portion of the mountain, which is above timber-line, must be peopled anew every year by female ants that never succeed in establishing colonies. These females (and the shorter-lived males, when these are found, as in the case of Lasius nixtus above recorded) undoubtedly drift to the summit while on their nuptial flight. This is shown by the relatively large number of winged females in the above list. They are in all probability indivicluals that have ascended to an unusual altitude and have been swept onto the mountain summit by an upper air current. This seems to be the only way of accounting for the peculiar occurrence of forms like Dolichoderus gagates in such a locality. This ant is not known to breed further north than the low pine-barrens of New Jersey, where it nests in the warm, white sand about clumps of grass and attends plant-lice on the pines and scrub oaks.* The occurrence of this insect on a mountain summit $6293 \mathrm{ft}$. high and some hundreds of miles further north must be regarded as accidental. Only in case the Dolichoderus females succeeded in establishing their colonies on the summit of Mt. Washington would this condition be truly analogous to that of certain plants like the eastern prickly pear (Opuntia opuntia) which grows in low sandy spots in Florida and on the rocky ledges of certain hilltops in New Jersey, New York and Massachusetts. A strictly parallel instance, however, seems to be presented by Titpinoma pruinosum Roger, an ant which I have taken in the sandy pine-barrens of New Jersey and on the summits of some of the Ramapo Mountains in southern New York, but not in intermediate stations.

-Conf. my paper: The North American ants of the Genus Dolichoderus, Bull. Am. Mrus. Nat. Hist. Vol. XXI, 1905. pp. 305-319. 
In the study of mountain faunas it is well to bear in mind what Forel says in his work on the ants of Switzerland*: "One should never judge of the habitat of a species from the elevations at which isolated males or females have been captured. We have, in fact, observed that these sexes always seek the summits for the purpose of mating. On a beautiful day in summer, they often alight in regions where their species cannot subsist, and where they soon perish. Thus M. Bugnion found males of Formica rufa and pratensis on the Hüfi Glacier and he brought me specimens of these ants from the summit of the Stätzerhorn (Grisons). I have myself taken males and females of these ants on the snowcovered ridge which separates the Engadine from the valley of Roseg between the Piz Surlei and the Piz Corwatsch. Now neither the formicaries of rufa nor the formicaries of pratensis are found above the region of pines, whereas the winged individuals just mentioned had ascended to that of the eternal snows. Hence a female Myrmecina Latreillei which I took at a considerable elevation in the Jura near Mont Tendre does not prove to me that the formicaries of this species subsist at such an altitude."

The absence of ant colonies on the summit of Mount Washington is to be attributed to the length and rigor of the winter at such an elevation. In the Rocky Mountains colonies are very abundant up to an altitude of 9000 to 10,000 $\mathrm{ft}$. and may be found even as high as timber-line between I I,000 and I $2,000 \mathrm{ft}$. I have observed this distribution on Pike's Peak, near Cripple Creek, and on the neighboring mountains. Very similar conditions seem to prevail in the Himalayas.

Bare, cold mountain tops thus appear to be a source of "catastrophic elimination" to those winged seeds of their species, the female ants. Other sources of such elimination are torrential showers occurring during or just after the marriage flight ; many birds, which are fond of eating winged ants; and drowning, as the result of long flights out to sea or over our Great Lakes. During the summer months the insect drift which is cast up on the beaches of Lake Michigan and Lake Superior sometimes contains thousands of dead female ants. Other less important agents of destruction are some of the solitary wasps that provision their nests with fema!e ants captured during or just after the marriage flight. Aphilanthops frigridus, for example, has been seen to capture and carry home our common Furmica fusca var. subsericea. Mr. H. L. Viereck has sent me specimens of these wasps collected together with their prey by $\mathrm{Mr}$. Morgan Hebard in Baraga County, Michigan. When we add to these destructive

*Les Fourmis de la Suisse, Zürich 1874, p. 211. 
agencies the attacks of lethal fungi and subterranean insects on the females after they have shut themselves off from the world in their earthern cells for the purpose of ovipositing and rearing their brood, we are able to understand why so very few of the myriads of female ants that annually take their nuptial flight, ever survive to become the mothers of flourishing colonies. 

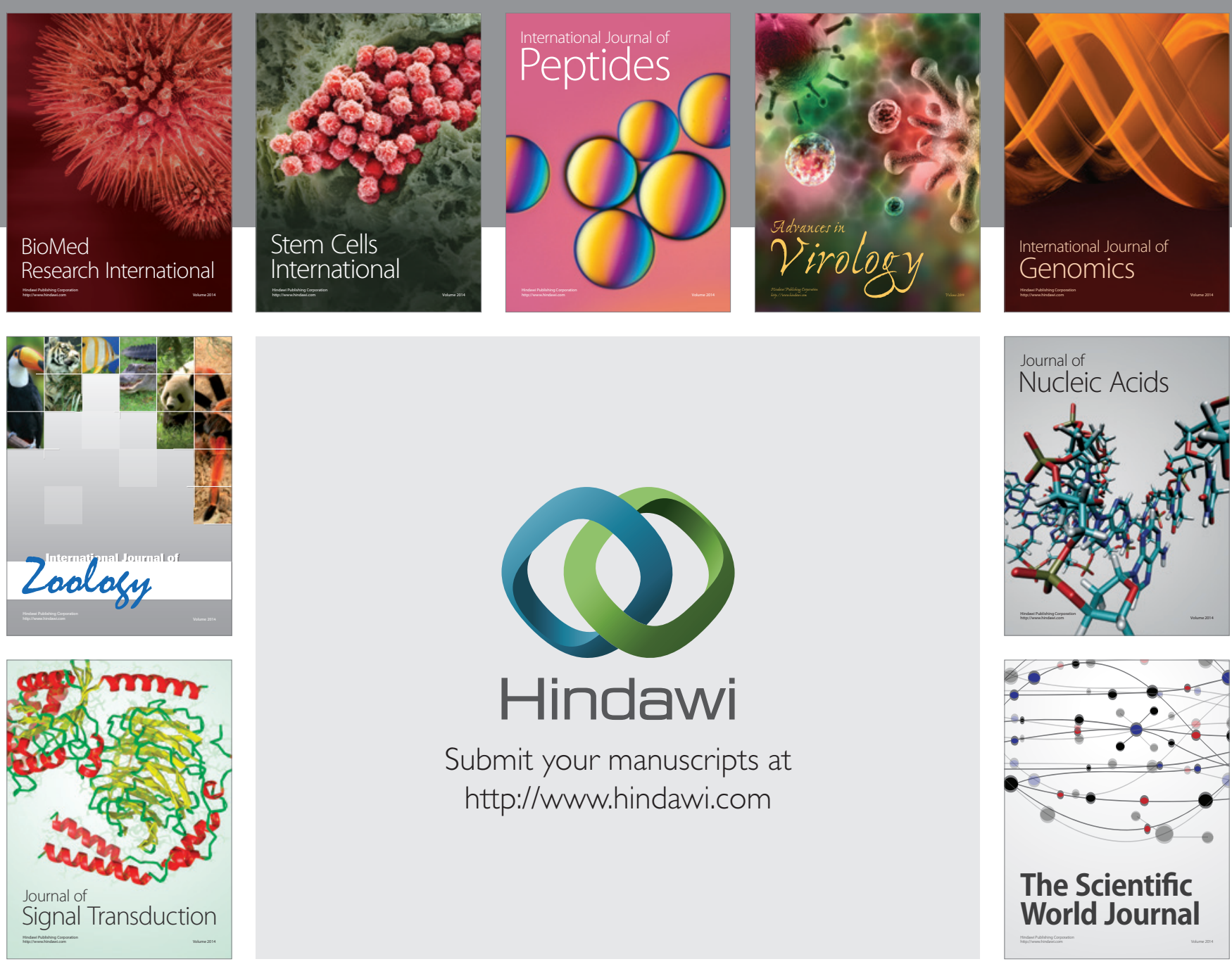

Submit your manuscripts at

http://www.hindawi.com
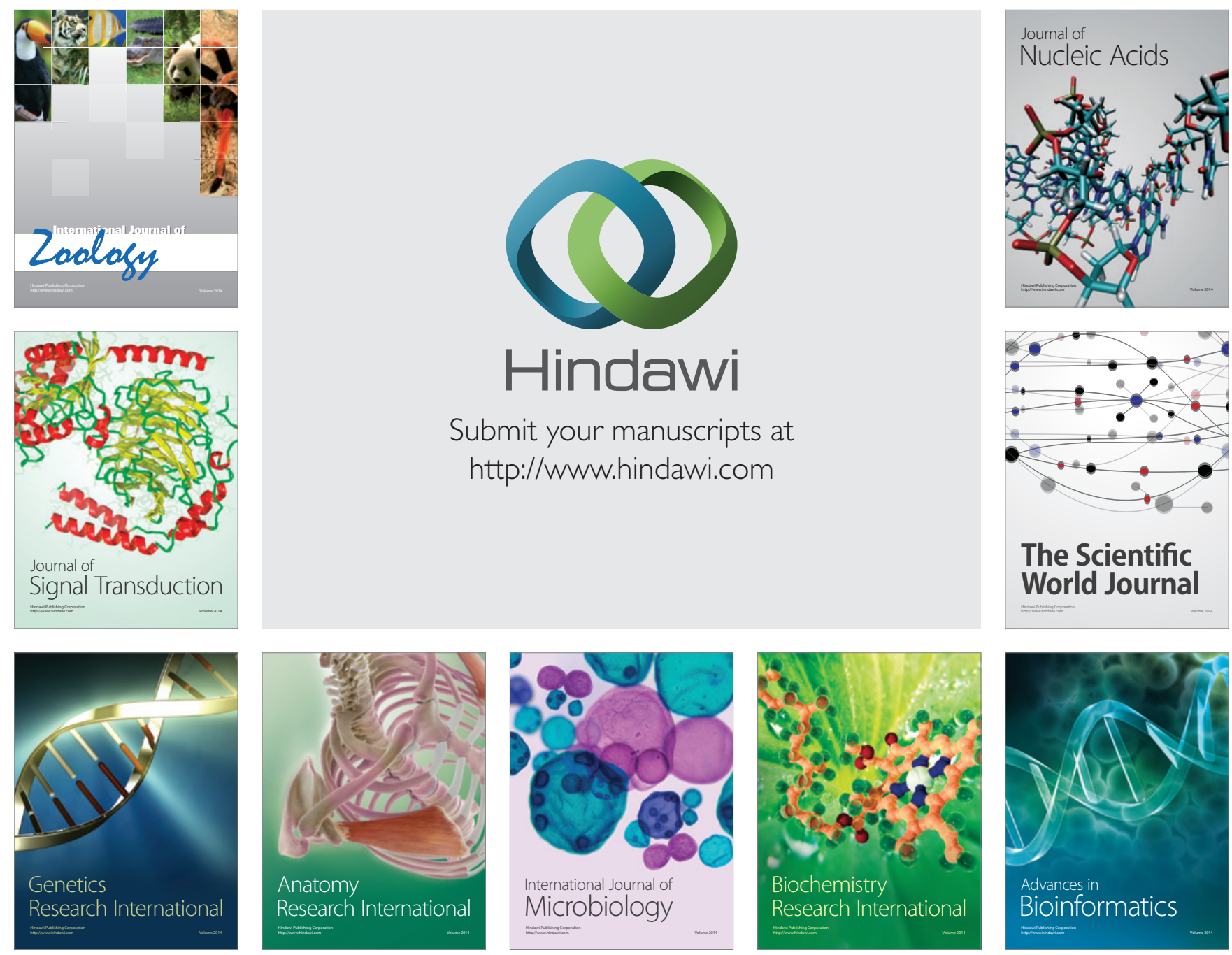

The Scientific World Journal
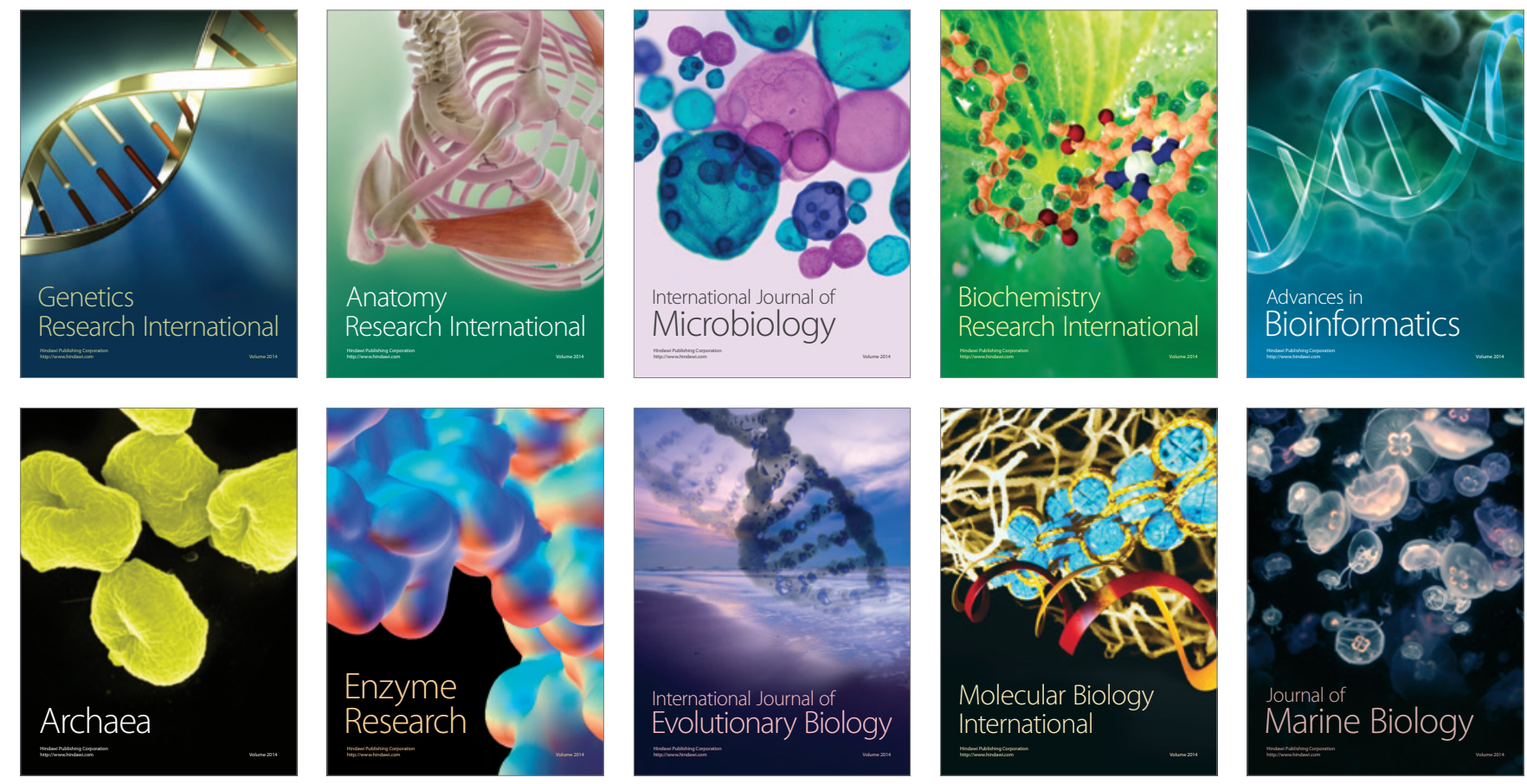